VIANA, JS; PALARETTI, LF; FARIA, RT; DELGADO, YV; DALRI, AB; BARBOSA, JA. 2020. Potato production affected by fertilization methods, masses of seed tubers and water regimes. Horticultura Brasileira 38: 166-174. DOI - http://doi.org/10.1590/S0102-053620200209

\title{
Potato production affected by fertilization methods, masses of seed tubers and water regimes
}

\author{
Jonathan dos S Viana ${ }^{1 \mathbb{D}}$; Luiz Fabiano Palaretti ${ }^{1 \mathbb{D}}$; Rogério T de Faria ${ }^{1 \mathbb{D}}$; Yago V Delgado ${ }^{1 \mathbb{D}}$; Alexandre \\ B Dalri ${ }^{1 \mathbb{D}}$; José de A Barbosa ${ }^{1 \mathbb{D}}$
}

${ }^{1}$ Universidade Estadual Paulista (UNESP), Jaboticabal-SP, Brasil; jonathan_santu@hotmail.com; luiz.f.palaretti@unesp.br; rogerio.faria@ unesp.br; yago_araxa@hotmail.com; alexandre.dalri@unesp.br; josearruda777@gmail.com

\begin{abstract}
Increasing potato yield while saving natural resources is a challenge for all those involved in the potato production chain. A field experiment was carried out in order to evaluate the effect of different levels of fertilization, mass of seed tubers and the water regime on the production of potato $\mathrm{cv}$. Orchestra. We tested fertilization methods $(F 1=$ conventional fertilization; $F 2=$ fertigation according to the rate of absorption by the crop; F3= fertigation split into 3 applications), seed tuber mass $(\mathrm{ST} 1=<50 \mathrm{~g}$; ST2 $=>50 \mathrm{~g})$, and water regimes [WR1= $50 \%$; WR2 $=100 \%$ replacement of crop evapotranspiration (ETc)]. The study was conducted using a split-plot randomized block design, with fertilizers in the plot and seed tuber mass in the subplot, with six replications. The highest tuber yields $\left(48.18 \mathrm{t} \mathrm{ha}^{-1}\right)$ and greatest potatoes $\left(43.67 \mathrm{t} \mathrm{ha}^{-1}\right)$ were obtained in the treatment F2 and for seed tuber masses $>50 \mathrm{~g}$ (48.61 and $\left.42.78 \mathrm{t} \mathrm{ha}^{-1}\right)$ under $100 \%$ ETc water regime. However, for plants subjected to $50 \% \mathrm{ETc}$, the factors fertilization and seed tuber mass caused no difference in tuber yield $(\mathrm{P}>0.05)$. The highest water use efficiency $\left(39.82 \mathrm{~kg} \mathrm{~m}^{-3}\right.$ of water) was found under WR of 50\% ETc for seed tuber masses $>50 \mathrm{~g}$. The highest cover ratio was obtained with tubers under $100 \%$ ETc being 89 days the cycle duration. The fertilization method and seed tuber mass that positively influenced the studied variables were fertigation according to the culture absorption rate and seed tuber masses $>50 \mathrm{~g}$ for both water conditions ( $100 \%$ and $50 \% \mathrm{ETc})$.
\end{abstract}

Keywords: Solanum tuberosum, drip irrigation, nutrition, propagation.

\section{RESUMO}

Produção de batata sob diferentes métodos de fertilização, massas de tubérculos sementes e regimes hídricos

Aumentar a produtividade da batateira economizando recursos naturais é um desafio de todos os envolvidos na cadeia produtiva da batata. Foi realizado um experimento de campo com o objetivo de avaliar o efeito de diferentes níveis de fertilização, massa de tubérculos sementes e regime hídrico sobre a produção de batata cv. Orchestra. Os tratamentos testados foram forma de fertilização (F1= adubação convencional; F2 = fertirrigação de acordo com a marcha de absorção da cultura; F3 = fertirrigação parcelada em 3 vezes), massa de tubérculo semente $(\mathrm{TS} 1=<50 \mathrm{~g}$; TS2 $=>50 \mathrm{~g})$, regimes hídricos $[\mathrm{RH} 1=50 \%$; RH2 $=100 \%$ de reposição da evapotranspiração de cultura (ETc)]. O estudo foi conduzido no delineamento em blocos casualizados, em parcelas subdivididas com fertilizações na parcela e massa de tubérculos sementes na subparcela, com seis repetições. Maior produtividade $\left(48,18 \mathrm{tha}^{-1}\right)$ e batata graúda $\left(43,67 \mathrm{tha}^{-1}\right)$ foram obtidas no tratamento fertirrigação (marcha de absorção) e massas de

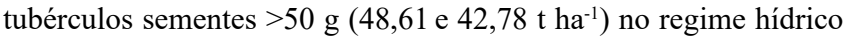
$100 \%$ ETc. Porém não houve diferenças nos fatores fertilização e massa de tubérculos sementes para as plantas submetidas ao regime $50 \%$ ETc para a variável produtividade de tubérculos $(\mathrm{P}>0,05)$. Maior eficiência do uso da água é atribuída ao RH1 50\% ETc para tubérculos sementes maiores que $50 \mathrm{~g}_{\text {de }} 39,82 \mathrm{~kg} \mathrm{~m}^{-3}$ de água. A maior razão de cobertura é atribuída a tubérculos sob regime $100 \%$ ETc e duração do ciclo de 89 dias. A forma de fertilização e massa de tubérculos sementes que influenciaram positivamente as variáveis estudadas foram a fertirrigação de acordo com a marcha de absorção da cultura e massas de tubérculos sementes $>50 \mathrm{~g}$ para as duas condições hídricas (100\% e 50\% ETc).

Palavras-chave: Solanum tuberosum, irrigação por gotejamento, nutrição, propagação.

Received on October 14, 2019; accepted on March 27, 2020

$\mathrm{P}$ otato (Solanum tuberosum) is one of the most planted and consumed vegetables worldwide. It is the fourth most important crop in the world in terms of production volume, followed by wheat (Triticum aestivum), rice (Oriza sativa) and maize (Zea mays), feeding more than half of the world's population (FAOSTAT, 2018).

Potato tubers provide human food, due to high contents of carbohydrates, besides minerals, fibers, proteins and antioxidant compounds such as polyphenols and vitamins, which contribute to the maintenance of consumers' health. The levels of these bioactive compounds present in the tubers are influenced by the cultivar, climatic conditions and cultural management (André et al., 2009).

According to FAOSTAT (2018), 
China is the production leader with about $9910^{6} \mathrm{t}$, while Brazil occupies only the $20^{\text {th }}$ place in this ranking, with total production of $3.610^{6} \mathrm{t}$. In São Paulo State, Brazil, the production of $228,880 \mathrm{t}$ in the first season and 266,200 $\mathrm{t}$ in the second season (IBGE, 2018) give the state a prominent position with respect to the cultivation of this vegetable. In addition to the income generated with the production, the need for intensive cultivation practices generates jobs, which help maintaining worker in the rural area.

Potato is one of the crops with largest requirements in terms of agricultural fertilizers per hectare (Nick \& Borém, 2017), making it highly demanding with respect to this input. With a cycle of 90 to 110 days, the maximum absorption of $\mathrm{N}, \mathrm{P}, \mathrm{Ca}, \mathrm{Mg}$ and $\mathrm{S}$ occurs in the initial stage (45 to 70 days after planting) of tuber filling. $\mathrm{K}$ absorption is more concentrated between 40 and 60 DAP (Fernandes et al., 2011).

Mantovani et al. (2014), in a study evaluating the yield of drip-irrigated potatoes, applied the following amounts of fertilizer: 3.13 tha $^{-1}(04-12-08)$ in the planting furrow; $0.9 \mathrm{t} \mathrm{ha}^{-1}$ (18-00-12) as top-dressing (pile-up) and at 25 days after planting (DAP).

Bavuso Neto et al. (2010), studying the technical viability of fertigation in potato crop with the fertigation factors (surface and subsurface); nitrogen $\left(0.075 ; 0.150\right.$ and $\left.0.225 \mathrm{t} \mathrm{ha}^{-1}\right)$; potassium $(0.210 ; 0.310$ and $0.410 \mathrm{t}$ $\left.\mathrm{ha}^{-1}\right)$, concluded that it is possible to produce fertigated potatoes using a localized irrigation system, regardless of being surface or subsurface.

However, the constant commercial fluctuations and the historical increase in prices directly affect the production costs, and to increase the efficiency in the use of fertilizers their application via irrigation water becomes an important strategy. Fertigation allows greater control in the amount of fertilizer applied, as well as the splitting of the recommended doses, besides reducing the costs with labor, machinery and time spent for agricultural operations (Embrapa, 2004).

Another important and decisive input in the success of potato cultivation is the seed tuber, which accounts for 30 to $45 \%$ of the total production cost (Filgueira, 2013) and can directly affect the production and financial return of the crop. Teixeira et al. (2010), identifying the size of seed potato leading to highest efficiency in emergence and yield, found that the larger the size of the seed tuber, the greater the number of buds, shoots and consequently a greater number of stems, becoming possible to observe that the larger the size of the seed potato, the higher the yield.

In São Paulo state, the occurrence of water deficit is frequent due to the irregular rainfall during the potato growth cycle (Soriano et al., 2016). Water deficit affects the production and quality of potatoes, and irrigation is necessary to supplement the precipitation. Potato tubers are very sensitive to water stress, because the root system is shallow and dispersed, with $85 \%$ of the roots in the first $30 \mathrm{~cm}$ soil depth (Iwama, 2008). The use of irrigation systems and more efficient management practices are required to ensure the economic and environmental sustainability of potato production.

Given the scenario of competitiveness for water use and problems related to the availability of water resources, alternatives are necessary for saving this input in irrigation (Silva et al., 2007). In this context, researchers have investigated the performance, as well as cultivation and management strategies, for the adoption of irrigation systems characterized by promoting a reduction in water waste. Thus, it is important to conduct studies that define the appropriate time to irrigate and the amount of water to be applied and result in more precise information on the water requirement of the crop (Geisenhoff et al., 2016), because the water requirement of potato is variable according to the edaphoclimatic conditions.

Drip irrigation has been successfully evaluated and adopted for several crops, including potato. In a study in Turkey, Erdem et al. (2006) obtained higher water use efficiency in potato cultivation under drip irrigation, compared to furrow irrigation. Mantovani et al. (2014), in southern Minas Gerais state,
Brazil, applying $300 \mathrm{~mm}$ water through drip irrigation using conventional fertilization in the potato cultivar Agata, obtained yield of $61 \mathrm{t} \mathrm{ha}^{-1}$, in which $50.3 \mathrm{t} \mathrm{ha}^{-1}$ consisted of large potatoes with $40.08 \mathrm{~kg}$ tuber per $\mathrm{m}^{3}$ of water applied, for the irrigation frequency of 4 days. Zhou et al. (2018), in a study in Denmark using drip fertigation, obtained yields of 48,43 and $40 \mathrm{tha}^{-1}$ in 2013, 2014 and 2015, respectively.

Due to the great importance of the potato crop, the objective of this study was to evaluate the effect of diverse fertilization methods, seed tuber masses and water regimes on production of the potato $\mathrm{cv}$. Orchestra.

\section{MATERIAL AND METHODS}

The experiment was conducted at UNESP, Campus of Jaboticabal, São Paulo, Brazil (21 ${ }^{\circ} 15 ’ 22^{\prime}$ 'S, $48^{\circ} 18^{\prime} 58^{\prime \prime} \mathrm{W}, 595 \mathrm{~m}$ altitude). According to Köppen's classification, the climate of the region is Aw, tropical, with 1,340 $\mathrm{mm}$ precipitation, concentrated in the summer, and $21.7^{\circ} \mathrm{C}$ average annual temperature, hot summers and mild winters (CEPAGRI, 2016).

The soil is classified as Latossolo Vermelho distrófico típico (Oxisol), clayey texture, moderate $\mathrm{A}$ horizon, iron oxide contents $<8 \%$ and $\left(\mathrm{SiO}_{2}\right) /\left(\mathrm{Al}_{2} \mathrm{O}_{3}\right.$ $+\mathrm{Fe}_{2} \mathrm{O}_{3}$ ) ratio $>0.75$ (Embrapa, 2018).

The chemical characterization on the 0-20 cm layer showed: organic matter $=21 \mathrm{~g} \mathrm{dm}^{-3} ; \mathrm{pH}\left(\mathrm{CaCl}_{2}\right)=5.8 ; \mathrm{P}_{2} \mathrm{O}_{5}=$ $48 \mathrm{mg} \mathrm{dm}^{-3} ; \mathrm{K}_{2} \mathrm{O}=1.8 \mathrm{mmol}_{\mathrm{c}} \mathrm{dm}^{-3}$; $\mathrm{Ca}=40 \mathrm{mmol}_{\mathrm{c}} \mathrm{dm}^{-3} ; \mathrm{Mg}=17 \mathrm{mmol}_{\mathrm{c}}$ $\mathrm{dm}^{-3} ; \mathrm{V}=72 \%$. For the $20-40 \mathrm{~cm}$ layer showed organic matter $=12 \mathrm{~g} \mathrm{dm}^{-3} ; \mathrm{pH}$ $\left(\mathrm{CaCl}_{2}\right)=5.4 ; \mathrm{P}_{2} \mathrm{O}_{5}=10 \mathrm{mg} \mathrm{dm}^{-3} ; \mathrm{K}_{2} \mathrm{O}=$ $3.3 \mathrm{mmol}_{\mathrm{c}} \mathrm{dm}^{-3} ; \mathrm{Ca}=21 \mathrm{mmol}_{\mathrm{c}} \mathrm{dm}^{-3}$; $\mathrm{Mg}=12 \mathrm{mmol}_{\mathrm{c}} \mathrm{dm}^{-3} ; \mathrm{V}=58 \%$.

Soil samples for nutritional and moisture retention analyses were collected in the $0-40 \mathrm{~cm}$ layer, which contained $90 \%$ of active roots and was considered the irrigation managing depth.

The analyses were carried out before and during the experiments. Soil volumetric moisture content ranged from $26.82 \%$ to $43.82 \%$ and from $26.36 \%$ to $43.81 \%$ in the layers of $0-0.2$ 
$\mathrm{m}$ and $0.2-0.4 \mathrm{~m}$ respectively, during the conduction of the field experiments.

\section{Experimental procedures}

The second-generation tubers of cv. Orchestra were manually planted at density of 4.44 plants $\mathrm{m}^{-2}$, on May 9,2018 , in 3 cultivation rows, with 18 plants per row, in plots of $2.25 \mathrm{~m} \mathrm{x} 5.40$ $\mathrm{m}$. This cultivar has a short to medium cycle, with medium dormancy and little apical dominance, which allows storing the seeds for a long period and, once removed from the cold chamber, the tubers presented no sprouting or very fast reserve depletion.

We evaluated three forms of fertilization $(\mathrm{F} 1=$ conventional fertilization; $\mathrm{F} 2=$ fertigation according to the rate of absorption by the crop; F3= fertigation split into three applications), two seed tuber masses $(\mathrm{ST} 1=<50 \mathrm{~g}$; $\mathrm{ST} 2=>50 \mathrm{~g}$ ), and two water regimes [WR $1=50 \%$; WR $2=100 \%$ replacement of crop evapotranspiration (ETc)]. The experiment was conducted in randomized blocks, in split plots, with fertilizations in the plots and seed tuber mass in the subplot, with 6 replicates.

The masses of seed tubers $<50 \mathrm{~g}$ used in the planting varied from 36.67 to $40.52 \mathrm{~g}$ whereas the mass of seed tubers $>50 \mathrm{~g}$ varied from 79.86 to $120.26 \mathrm{~g}$.

According to the soil analysis, as recommended by Bulletin 100 of IAC (Van Raij et al., 1997), $2 \mathrm{t} \mathrm{ha}^{-1}$ of NPK (6-30-15) were applied at seed tuber planting date in all treatments.

The treatments were differentiated with the top-dressing fertilizations performed from 35 days after planting (DAP). Treatments under the F1 level received $0.50 \mathrm{t} \mathrm{ha}^{-1}$ of NPK (12-0612) in a single application; treatments under the F2 level received $0.39 \mathrm{tha}^{-1}$ of Calcinit (source of N) (Calcinit $15.5 \% \mathrm{~N}$; Yara, Porto Alegre-RS, Brasil) and $0.12 \mathrm{t} \mathrm{ha}^{-1}$ of Krista SOP (source of $\mathrm{K}$ ) (Krista SOP $51 \% \mathrm{~K}_{2} \mathrm{O}$; Yara, Porto Alegre-RS, Brasil), following the rate of absorption by the crop; and treatments under the F3 level received $0.39 \mathrm{t} \mathrm{ha}^{-1}$ of Calcinit and $0.12 \mathrm{tha}^{-1}$ of Krista SOP through fertigation split into 3 applications, according to the fertilization schedule (Table 1).
In addition to fertilization at planting date and as top-dressing, there were also four foliar applications of the product Cálcio e Cobre (Cálcio e Cobre; Base fértil, Cravinhos-SP, Brasil), source of Ca 5\% (57.5 g L $\left.\mathrm{g}^{-1}\right), \mathrm{S} 1.5 \%\left(17.25 \mathrm{~g} \mathrm{~L}^{-1}\right)$ and $\mathrm{Cu} 3 \%\left(34.5 \mathrm{~g} \mathrm{~L}^{-1}\right)$ at a concentration of $1 \mathrm{~L} \mathrm{ha}^{-1}$.

Chemical control of weeds was performed by applying Metribuzim (Sencor ${ }^{\circ}$; Bayer, Parque Industrial de Belford Roxo-RJ, Brasil) (0.75$\left.1.5 \mathrm{~L} \mathrm{ha}^{-1}\right)$ in pre-emergence and Paraquat (Gramoxone ${ }^{\odot}$; Syngenta, São Paulo-SP, Brasil) (0.5 $\left.\mathrm{L} \mathrm{ha}^{-1}\right)$ in post-emergence. Pests and fungi were controlled preventively, based on climatic variations and observations in the field, using products registered for potato crop. Chemical control of weeds was performed by applying Sencor (0.75-1.5 $\left.\mathrm{L} \mathrm{ha}^{-1}\right)$ in preemergence and Gramoxone ( $\left.0.5 \mathrm{~L} \mathrm{ha}^{-1}\right)$ in post-emergence. Pests and fungi were controlled preventively, based on climatic variations and observations in the field, using products registered for potato crop.

\section{Meteorological conditions and irrigation management}

Plant rows were irrigated by a drip system with lines spaced $0.30 \mathrm{~m}, 1.6 \mathrm{~L}$ $\mathrm{h}^{-1}$ discharge, $1.3 \mathrm{kgf} \mathrm{cm}^{-2}$ pressure, in a uniformity coefficient of Christiansen (Denículi et al., 1980) of $89.8 \%$, determined in the field, which can be considered an excellent uniformity for drip irrigation (Bernardo et al., 2007).

Meteorological data were obtained from the agro-climatological station of FCAV, located close to the experiment, and used to calculate the reference evapotranspiration (ETo) by the Penman-Monteith method. The replacement of water consumption by the crop was determined by the crop evapotranspiration, calculated as the product of ETo and crop coefficients, according to the development stages of the crop [I= initial $(0.45-0.55)$ from 0 to 9 days duration; $\mathrm{I}=$ vegetative (0.45-0.55) from 10 to 29 days; $\mathrm{III}=$ stolonization/tuberization (0.75-0.85) from 30 to 49 days; IV= tubers growth (1.00-1.10) from 50 to 70 days of duration, and $\mathrm{V}=$ maturation $(0.65-0.75)$ with phenological stage duration from 71 to 89 days after planting (Allen et al., 1998, Marouelli \& Guimarães, 2006)].

The conditions under which the potato cultivar Orchestra was grown were adequate for good agronomic performance. Average air temperature during the experiment was $20.6^{\circ} \mathrm{C}$, $14.0^{\circ} \mathrm{C}$ and $28.1^{\circ} \mathrm{C}$ average minimum and maximum temperatures respectively, and $15.27 \mathrm{MJ} \mathrm{m}^{-2}$ average solar radiation. The temperature remained within the range from 10 to $20^{\circ} \mathrm{C}$, considered ideal for potato development. Very high temperature favors shoot growth and reduces production (Heldwein et al., 2009). According to Streck et al. (2007), potato is a short-day culture for the start of tuberization and day-neutral or long-day for flowering.

The average reference evapotranspiration (ETo) during the crop cycle was $2.39 \mathrm{~mm}$ in the sprouting, $1.98 \mathrm{~mm}$ in the vegetative stage, 2.15 $\mathrm{mm}$ in the stolonization stage, 2.20 $\mathrm{mm}$ in the tuber filling stage, and 2.59 $\mathrm{mm}$ in maturation. The average crop evapotranspiration (ETc) was $2.03 \mathrm{~mm}$ (Figure 1).

The plants subjected to the WR of $100 \%$ ETc received $190.3 \mathrm{~mm}$ total water depth during the cycle, 164.4 $\mathrm{mm}$ from irrigation and $25.9 \mathrm{~mm}$ from precipitation, while plants subjected to WR of $50 \%$ ETc received $74.8 \mathrm{~mm}$ total water depth, of which $74.6 \mathrm{~mm}$ corresponded to irrigation and $0.2 \mathrm{~mm}$ to precipitation (Figure 1). Seasonal precipitation was higher for the WR of $100 \%$ ETc due to the longer growing season in this treatment ( 89 days), as compared to the WR of 50\% ETc water regime, which had shorter cycle (75 days). During the additional period of 14 days in the WR of $100 \%$ ETc, precipitation was $25.9 \mathrm{~mm}$.

\section{Evaluated parameters}

At the end of the cultivation cycles, at 75 DAP in the treatments under WR of $50 \%$ ETc and at 89 DAP in the treatments under WR of $100 \%$ ETc, plants were desiccated with the herbicide Gramoxone $\odot\left(2 \mathrm{~L} \mathrm{ha}^{-1}\right)$ and harvested after 14 days, selecting 12 
plants from the central row, with three border plants for each end.

Tuber production was evaluated in three forms: total yield, weight of the harvested tubers and percentage of marketable tubers. In each plot, all tubers from 12 plants were harvested. These tubers were analyzed for transverse diameter using a digital caliper (316119 mtx; Nakao, São Paulo-SP, Brasil) and classified as large potatoes $(\geq 45 \mathrm{~mm}$, classes I and II) and small potatoes $(<45 \mathrm{~mm}$, classes III-V) (IBQH, 2003). Tubers of each size were weighed using a WH-A08 handheld digital scale with $10 \mathrm{~g}$ precision (Tomate WH-A08; Filivale, São José dos Campos-SP, Brasil).

Total production was calculated by the sum of the weights of all tubers in each category. The results were expressed in $\mathrm{tha}^{-1}$.

The production of marketable tubers was determined by the total mass of tubers classified as large tubers, divided by the total production of all tubers.

The cover ratio, which correlates the area covered by the potato plant in a known area, was determined using Canopeo ${ }^{\circledR}$ software (Canopeo ${ }^{\circledR}$; Universidade de Oklahoma, EUA), and the water use efficiency (WUE) was obtained by the ratio between total production of tubers per unit of consumed water, with values expressed in $\mathrm{kg}$ of tuber $\mathrm{m}^{-3}$ of water.

\section{Statistical analysis}

The analysis of variance (ANOVA) was carried out separately for each water regime, assuming normal data distribution, and the means were compared by Tukey test $(\mathrm{p}<0.05)$, using Agroestat software, version 1.0 (Barbosa \& Maldonado Júnior, 2015).

\section{RESULTS AND DISCUSSION}

\section{Total yield}

For the WR of $50 \% \mathrm{ETc}$, the analysis of variance of tuber yield did not reveal statistical difference caused by the type of fertilization, but there was statistical difference due to seed tuber mass (Table 2). There was no interaction between the analyzed factors. The comparison of means showed higher yield (29.55

$\left.\mathrm{t} \mathrm{ha}^{-1}\right)$ in the treatment with seed tuber mass $>50 \mathrm{~g}$, which was $36.2 \%$ higher

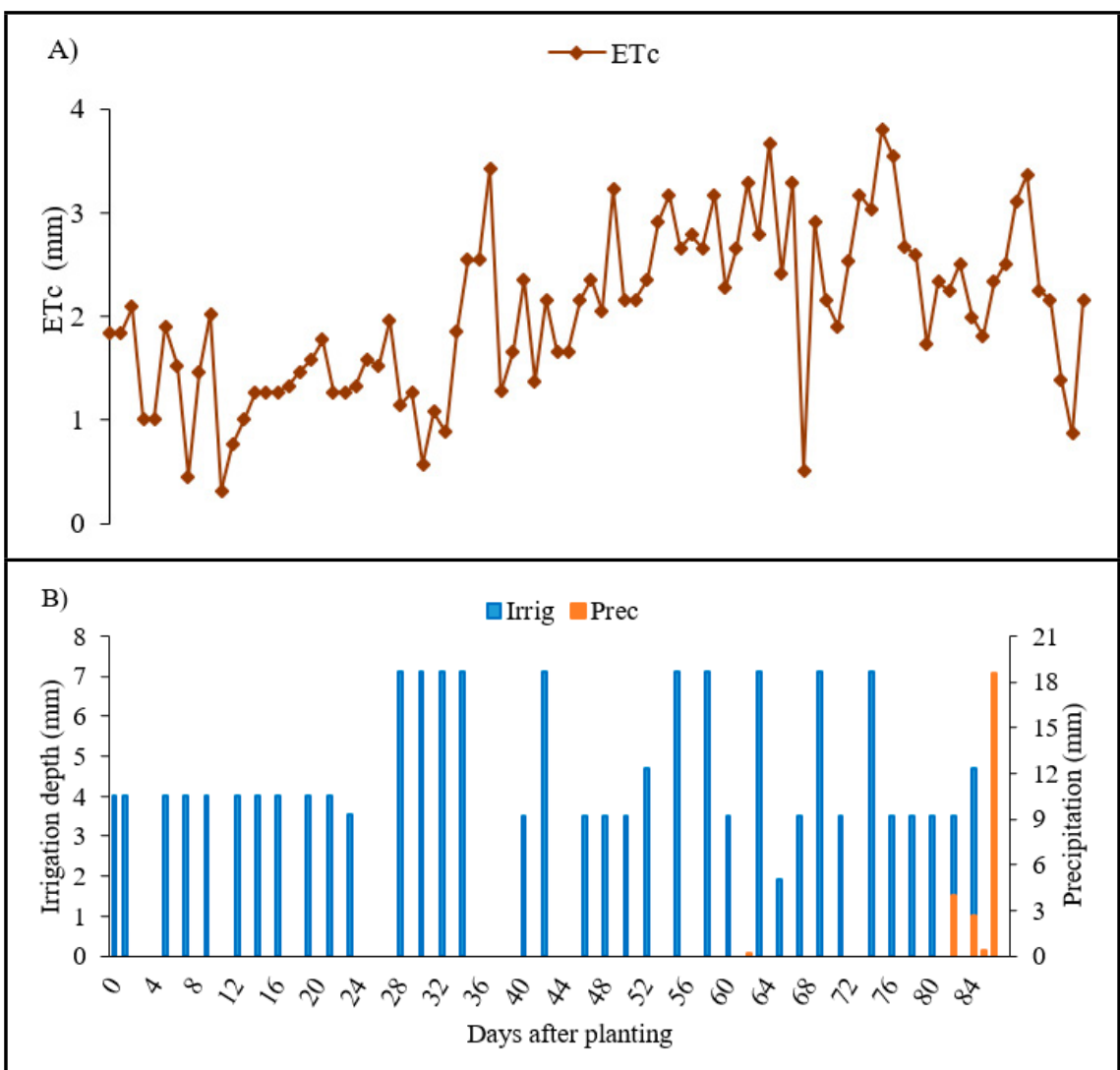

Figure 1. Crop evapotranspiration (ETc) (A), irrigation (Irrig) and precipitation (Prec) (B), along the cultivation of the potato cv. Orchestra. Jaboticabal, UNESP, 2018.

Table 1. Fertigation schedule during the cycle of the potato cv. Orchestra. Jaboticabal, UNESP, 2018

\begin{tabular}{|c|c|c|c|c|c|}
\hline \multirow{2}{*}{ Crop stage } & \multirow{2}{*}{ DAP } & \multicolumn{2}{|c|}{$\begin{array}{c}\text { Fertigation } \\
\text { (absorption rate, \%) }\end{array}$} & \multicolumn{2}{|c|}{$\begin{array}{l}\text { Split fertigation } \\
\text { (\%) (3x) }\end{array}$} \\
\hline & & Calcinit $^{\mathrm{a}}$ & Krista SOP & Calcinit & Krista SOP \\
\hline \multirow{4}{*}{$\begin{array}{l}\text { Vegetative } \\
\text { growth }\end{array}$} & 7 & 0.00 & 0.00 & 0.00 & 0.00 \\
\hline & 14 & 2.40 & 1.68 & 0.00 & 0.00 \\
\hline & 21 & 4.39 & 4.07 & 0.00 & 0.00 \\
\hline & 28 & 6.40 & 6.10 & 21.16 & 24.00 \\
\hline Tuberization & 35 & 8.00 & 11.87 & 0.00 & 0.00 \\
\hline \multirow{7}{*}{ Tuber filling } & 42 & 11.20 & 15.60 & 42.72 & 58.00 \\
\hline & 49 & 20.40 & 30.52 & 0.00 & 0.00 \\
\hline & 56 & 11.60 & 11.87 & 0.00 & 0.00 \\
\hline & 63 & 10.80 & 6.11 & 36.11 & 18.00 \\
\hline & 70 & 9.20 & 5.08 & 0.00 & 0.00 \\
\hline & 77 & 7.60 & 4.06 & 0.00 & 0.00 \\
\hline & 84 & 6.40 & 3.05 & 0.00 & 0.00 \\
\hline \multirow{2}{*}{ Maturation } & 87 & 1.60 & 0.00 & 0.00 & 0.00 \\
\hline & 90 & 0.00 & 0.00 & 0.00 & 0.00 \\
\hline
\end{tabular}

${ }^{\mathrm{a}}$ Calcinit (source of N 15,5\% and Ca 19\%); ${ }^{b}$ Krista SOP (source of K $51 \%$ and S $18 \%$ ). $\mathrm{DAP}=$ Days after planting. 
than that obtained with seed tubers $<50$ $\mathrm{g}\left(21.69 \mathrm{t} \mathrm{ha}^{-1}\right)$ (Table 2).

For the WR of $100 \% \mathrm{ETc}$, there was a significant difference caused by fertilization and seed tuber mass, and absence of significance for the interaction between the factors (Table 3 ). The highest yield (48.48 $\mathrm{tha}^{-1}$ ) was

Table 2. Comparison of means for tuber yield, classification of tubers as large potato and small potato, and percentage of marketable tubers of the potato cv. Orchestra subjected to fertilizations, seed tuber masses and water regime 50\% ETc. Jaboticabal, UNESP, 2018.

\begin{tabular}{|c|c|c|c|c|}
\hline \multicolumn{5}{|c|}{$50 \%$ ETc Water regime } \\
\hline Fertilizations (F) & 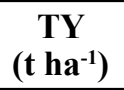 & $\begin{array}{c}\text { Bg } \\
\left(\mathbf{t ~ h a}^{-1}\right)\end{array}$ & 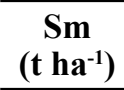 & $\begin{array}{c}\text { PMT } \\
(\%)\end{array}$ \\
\hline Conventional fertilization (F1) & $23.96 \mathrm{a}$ & $15.73 \mathrm{a}$ & $8.23 \mathrm{a}$ & $65.65 \mathrm{a}$ \\
\hline Fertigation (absorption rate) (F2) & $27.54 \mathrm{a}$ & $20.12 \mathrm{a}$ & $7.42 \mathrm{a}$ & $71.33 \mathrm{a}$ \\
\hline Fertigation (split into 3 applications) (F3) & $25.37 \mathrm{a}$ & $15.34 \mathrm{a}$ & $10.03 \mathrm{a}$ & $59.50 \mathrm{a}$ \\
\hline \multicolumn{5}{|l|}{ Seed tuber masses (ST) } \\
\hline Mass $<50 \mathrm{~g}(\mathrm{ST} 1)$ & $21.69 \mathrm{~b}$ & $14.07 \mathrm{~b}$ & $7.62 \mathrm{a}$ & $60.09 \mathrm{a}$ \\
\hline Mass > $50 \mathrm{~g}(\mathrm{ST} 2)$ & $29.55 \mathrm{a}$ & $20.05 \mathrm{a}$ & $9.50 \mathrm{a}$ & $66.82 \mathrm{a}$ \\
\hline \multicolumn{5}{|l|}{ ANOVA } \\
\hline Fertilizations $(\mathrm{F})$ & ns & ns & ns & ns \\
\hline Seed tuber mass (ST) & $* *$ & $* *$ & ns & ns \\
\hline $\mathrm{F} \times \mathrm{ST}$ & ns & ns & ns & ns \\
\hline
\end{tabular}

Means followed by same lowercase letters in the column do not differ by the Tukey's multiple means comparison test $(\mathrm{p}<0.05) ; * *$ significant $(\mathrm{p}<0.01)$; ns $=$ not significant. $\mathrm{TY}=$ Tuber yield; $\mathrm{Bg}=$ Large potato; $\mathrm{Sm}=$ Small potato; $\mathrm{PMT}=$ Percentage of marketable tubers.

Table 3. Comparison of means for tuber yield, classification of tubers as large potato and small potato, and percentage of marketable tubers of the potato cv. Orchestra subjected to fertilizations, seed tuber masses and water regime of 100\% ETc. Jaboticabal, UNESP, 2018.

\begin{tabular}{|c|c|c|c|c|}
\hline \multicolumn{5}{|c|}{$100 \%$ ETc Water regime } \\
\hline Fertilizations (F) & $\begin{array}{c}\text { TY } \\
\left(t \text { ha }^{-1}\right)\end{array}$ & $\begin{array}{c}\text { Bg } \\
\left(t^{\left(t h a^{-1}\right.}\right)\end{array}$ & $\begin{array}{c}\text { Sm } \\
\left(\mathrm{t} \mathrm{ha}^{-1}\right)\end{array}$ & $\begin{array}{c}\text { PMT } \\
(\%)\end{array}$ \\
\hline Conventional fertilization (F1) & $41.48 \mathrm{~b}$ & $37.48 \mathrm{~b}$ & $3.99 \mathrm{a}$ & $88.77 \mathrm{a}$ \\
\hline Fertigation (absorption rate) (F2) & $48.48 \mathrm{a}$ & $43.67 \mathrm{a}$ & $4.51 \mathrm{a}$ & $90.54 \mathrm{a}$ \\
\hline Fertigation (split into 3 applications) (F3) & $42.65 \mathrm{~b}$ & $37.83 \mathrm{~b}$ & $4.82 \mathrm{a}$ & $90.26 \mathrm{a}$ \\
\hline Seed tuber masses (ST) & 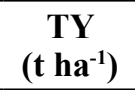 & $\begin{array}{c}\mathbf{B g} \\
\left(\mathbf{t} \mathbf{h a}^{-1}\right)\end{array}$ & $\begin{array}{c}\mathrm{Sm} \\
\left(\mathrm{t} \mathbf{h a}^{-1}\right)\end{array}$ & $\begin{array}{c}\text { PMT } \\
(\%)\end{array}$ \\
\hline Mass $<50 \mathrm{~g}(\mathrm{ST} 1)$ & $39.59 \mathrm{~b}$ & $36.53 \mathrm{~b}$ & $3.05 \mathrm{~b}$ & $91.92 \mathrm{a}$ \\
\hline Mass $>50 \mathrm{~g}(\mathrm{ST} 2)$ & $48.61 \mathrm{a}$ & $42.78 \mathrm{a}$ & $5.83 \mathrm{a}$ & $87.79 \mathrm{~b}$ \\
\hline \multicolumn{5}{|l|}{ ANOVA } \\
\hline Fertilizations $(\mathrm{F})$ & * & $*$ & * & $*$ \\
\hline Seed tuber mass (ST) & $* *$ & $* *$ & $* *$ & $*$ \\
\hline $\mathrm{F} \times \mathrm{ST}$ & ns & ns & ns & ns \\
\hline
\end{tabular}

*Means followed by same lowercase letters in the column do not differ by the Tukey's multiple means comparison test $(\mathrm{p}<0.05)$; ** significant $(\mathrm{p}<0.01)$; * significant $(\mathrm{p}<0.05)$; ns $=$ not significant. $\mathrm{TY}=$ Tuber yield $\mathrm{Bg}=$ Large potato; $\mathrm{Sm}=$ Small potato; $\mathrm{PMT}=$ Percentage of marketable tubers.
(Table 3).

The application of nutrients following the absorption march of potato cv. Orchestra promoted an increase in total productivity and large potatoes in the WR of $100 \%$ ETc (Table 3) due to the application of nutrients $\mathrm{N}$ and $\mathrm{K}$ at the time and in the appropriate amount for the crop, favoring a higher rate of nutrient absorption and translocation of these leaves for better tuber development. Such increases are also associated with fertigation (nutrients diluted in water) and the drip irrigation system, which has water application efficiency of 80 to $90 \%$, well above the 60 to $80 \%$ and 50 to $70 \%$ ranges, sprinkler and surface systems, respectively (Keller \& Bliesner, 1990).

\section{Large potatoes}

For the WR of $50 \%$ ETc, the analysis of variance of the yield of tubers classified as large potatoes showed no statistical difference caused by the type of fertilization, but there was statistical difference due to seed tuber mass (Table 2). There was no interaction between fertilization and seed tuber mass. The comparison of means showed higher production of potatoes classified as large (20.05 $\mathrm{t} \mathrm{ha}^{-1}$ ) in the treatment with seed tuber mass $>50 \mathrm{~g}$, which was $42.5 \%$ higher compared to seed tuber mass $<50$ $\mathrm{g}\left(14.07 \mathrm{t} \mathrm{ha}^{-1}\right)$ (Table 2).

For the WR of $100 \% \mathrm{ETc}$, there was a significant difference caused by fertilization and seed tuber mass for the production of large potatoes and no significance for the interaction between factors (Table 3 ). The highest yield of tubers classified as large potatoes was $43.67 \mathrm{t} \mathrm{ha}^{-1}$, obtained in the treatment Fertigation (absorption rate). The yield of potatoes classified as large with F1 and F3 fertilization rate were similar, 37.48 and $37.83 \mathrm{tha}^{-1}$, respectively. For the seed tuber mass factor, the highest quantity of potatoes occurred in ST2 (42.78 $\mathrm{t} \mathrm{ha}^{-1}$ ), which was $16.2 \%$ higher than that found with ST1 (36.53 tha $\left.\mathrm{th}^{-1}\right)(3)$.

The superiority of the treatment with greater mass of seed tubers for the variables total yield and large potatoes for both water regimes $(50 \%$ ETc and $100 \%$ ETc) (Table 2 and 3), can be 
attributed to the greater starch reserve for the full development of the plant in the field by supplying the aerial part that influenced these parameters. Queiroz et al. (2013) worked with the potato cultivar Ágata and found no statistically significant differences for total and commercial productivity, and commercial dry matter of tubers between the different spacing and types of seed potatoes (Types I and III), diverging from the results found in the present research.

Water directly influences the increase in shoot biomass, increasing its photosynthetic activity and directly impacting final productivity. Because it is considered a modified stem, both, water excess and deficit, affect crop production. Excess water can impair the development of potato crops and increase the incidence of soilrelated diseases, and the deficit limits production.

The lower the availability of water in the soil, the greater the stress on the plant, causing a reduction in stomatal opening and the lower the production of photoassimilates. This situation affects the final production of tubers, as observed in plants subjected to $50 \%$ ETc water regime (Table 2)

\section{Small potatoes}

For the WR of $50 \%$ ETc, the analysis of variance of the production of small potatoes did not reveal statistical difference caused by the type of fertilization and seed tuber mass (Table $2)$. There was no interaction between the factors fertilization and seed tuber mass.

For the WR of $100 \%$ ETc, there was no significant difference caused by fertilization, but significance was observed for seed tuber mass. There was no interaction between factors (Table $3)$. Greater amount of small potatoes occurred in ST2 (5.83 $\left.\mathrm{t} \mathrm{ha}^{-1}\right)$, which was $91.1 \%$ higher than that found in ST1

\section{Marketable tubers (\%)}

For the WR of $50 \%$ ETc, the analysis of variance of the percentage of marketable tubers did not show statistical difference caused by the type of fertilization and seed tuber mass
(Table 2). There was no interaction between the factors fertilization and seed tuber mass.

For the WR of $100 \%$ ETc, there was no significant difference caused by fertilization, but significance was found for seed tuber mass. There was no interaction between factors (Table 3). Larger quantity of marketable tubers was found in ST1 (91.92\%), 4.07\% higher compared to ST2 (87.79\%)
(Table 3).

\section{Cover ratio}

Under WR of $50 \%$ ETc, the duration of the crop cycle was 75 days and under $100 \%$ ETc the cycle was prolonged to 89 days (Figure 2). Potato plants subjected to the WR of $100 \%$ ETc advanced their peak cover by 10 days compared to those under water stress at 50\% ETc (Figure 2).

Table 4. Comparison of means for water use efficiency in tubers of the potato cv. Orchestra subjected to fertilizations, seed tuber masses and water regime of $50 \%$ ETc. Jaboticabal, Unesp, 2018.

\begin{tabular}{|c|c|}
\hline \multicolumn{2}{|c|}{$50 \%$ ETc Water regime } \\
\hline Fertilizations (F) & WUE (kg m ${ }^{-3}$ of water) \\
\hline Conventional fertilization (F1) & $32.28 \mathrm{a}$ \\
\hline Fertigation (absorption rate) (F2) & $37.11 \mathrm{a}$ \\
\hline Fertigation (split into 3 applications) (F3) & $34.19 \mathrm{a}$ \\
\hline \multicolumn{2}{|l|}{ Seed tuber masses (ST) } \\
\hline Mass $<50 \mathrm{~g}(\mathrm{ST} 1)$ & $29.23 \mathrm{~b}$ \\
\hline Mass > $50 \mathrm{~g}(\mathrm{ST} 2)$ & $39.82 \mathrm{a}$ \\
\hline \multicolumn{2}{|l|}{ ANOVA } \\
\hline Fertilizations $(\mathrm{F})$ & ns \\
\hline Seed tuber mass (ST) & $* *$ \\
\hline $\mathrm{F} \times \mathrm{ST}$ & ns \\
\hline
\end{tabular}

Means followed by the same lowercase letters in the column do not differ by the Tukey's multiple means comparison test $(\mathrm{p}<0.05)$; ** significant $(\mathrm{p}<0.01)$; ns $=$ not significant. WUE $=$ Water use efficiency.

Table 5. Comparison of means for water use efficiency in tubers of the potato cv. Orchestra subjected to fertilizations, seed tuber masses and water regime of $100 \%$ ETc. Jaboticabal, Unesp, 2018.

\begin{tabular}{lc}
\hline \multicolumn{2}{c}{$\mathbf{1 0 0 \% E T c}$ Water regime } \\
\hline Fertilizations (F) & WUE $\left(\mathbf{k g ~ m}^{-3}\right.$ of water) \\
\hline Conventional fertilization (F1) & $21.80 \mathrm{~b}$ \\
Fertigation (absorption rate) (F2) & $25.32 \mathrm{a}$ \\
Fertigation (split into 3 applications) (F3) & $22.42 \mathrm{~b}$ \\
\hline Seed tuber masses (ST) & $20.81 \mathrm{~b}$ \\
\hline Mass $<50$ g (ST1) & $25.55 \mathrm{a}$ \\
Mass $>50$ g (ST2) & $*$ \\
\hline ANOVA & $* *$ \\
\hline Fertilizations (F) & $\mathrm{ns}$ \\
Seed tuber mass (ST) & \\
F x ST &
\end{tabular}

Means followed by the same lowercase letters in the column do not differ by the Tukey's multiple means comparison test $(\mathrm{p}<0.05)$; **significant $(\mathrm{p}<0.01)$; *significant $(\mathrm{p}<0.05)$; $\mathrm{ns}=$ not significant. WUE $=$ Water use efficiency. 


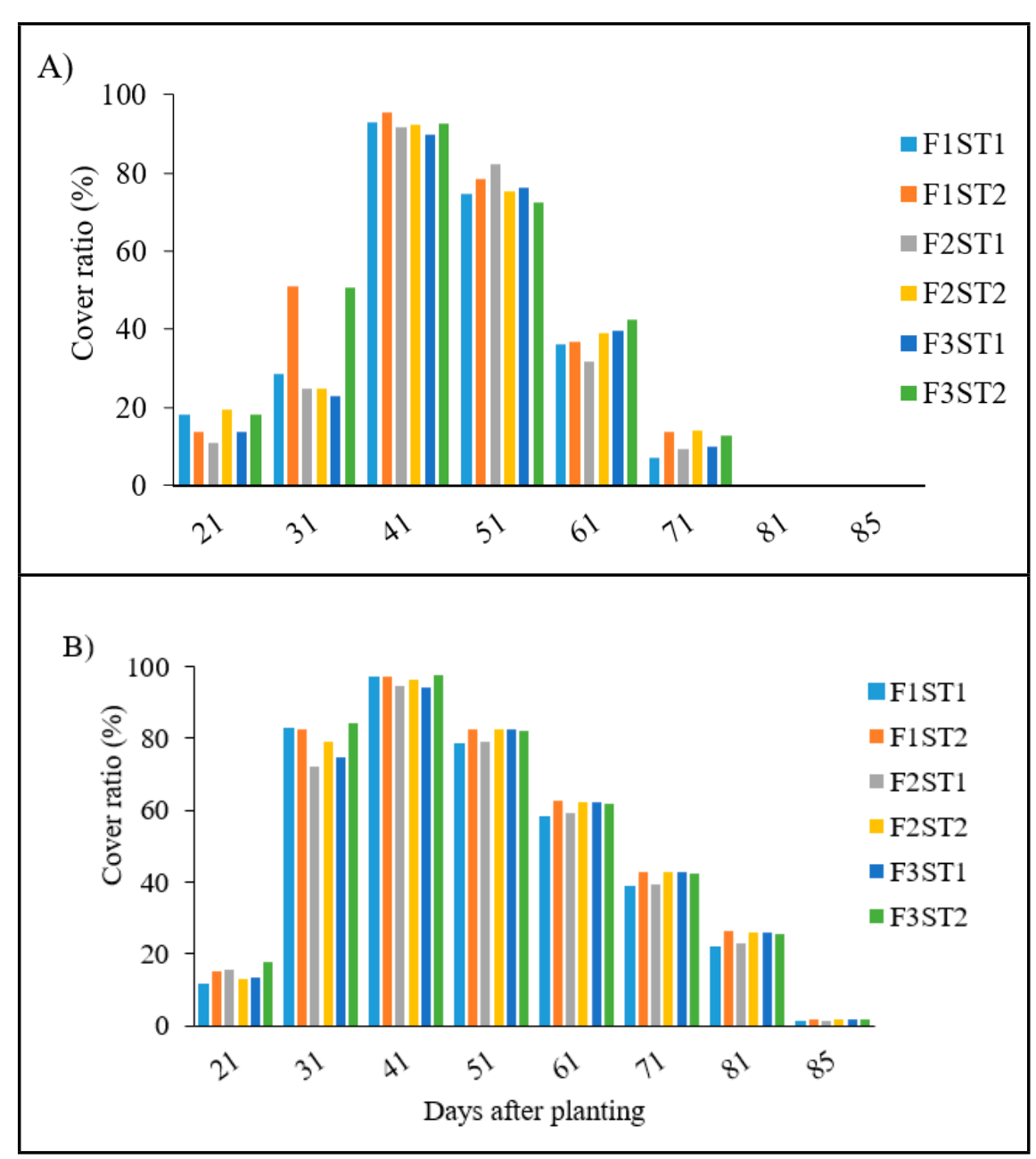

Figure 2. Cover ratio (\%) for the potato cv. Orchestra under water regimes of 50\% ETc (A) and $100 \%$ ETc (B). F1ST1 = Conventional fertilization and seed tuber mass $<50 \mathrm{~g}$; F1ST2= Conventional fertilization and seed tuber mass $>50 \mathrm{~g} ;$ F2ST1 $=$ Fertigation (absorption rate) and seed tuber mass $<50 \mathrm{~g} ; \mathrm{F} 2 \mathrm{ST} 2=$ Fertigation (absorption rate) and seed tuber mass $>50 \mathrm{~g}$; F3ST1 $=$ Fertigation (split into 3 applications) and seed tuber mass $<50 \mathrm{~g}$; F3ST2 $=$ Fertigation (split into 3 applications) and seed tuber mass $>50$ g. Jaboticabal, UNESP, 2018.

In relation to the fertilizations and mass of seed tubers for water regime of $100 \% \mathrm{ETc}$, there was little variation in the cover ratio along the crop cycle, compared to the stress condition (50\% ETc). At 31 DAP, there were higher peak covers for the treatments F1ST2 and F3ST2, equal to $50 \%$ and $49 \%$, respectively; however, at 41 DAP these treatments were equal to others.

The results of a higher coverage ratio (Figure 2) under the $100 \%$ water regime indicate that there is greater capture of solar radiation and, consequently, a higher rate of photosynthesis, influencing the increase in productivity and also favoring the increase in marketable tubers.

Longer-cycle plants generally have higher productivity because they have more time to vegetate and accumulate production. In addition, potatoes with a longer cycle are exposed more time to the adverse conditions of the environment, which can compromise the final production. However, there was no incidence of diseases related to the soil and the area for potatoes in the condition of water regime $100 \%$ ETc (Figure 2).

Silva \& Pinto (2005) emphasize that, in tropical conditions, potato clones with a late cycle are more productive than the earliest ones and suggest that the selection of late clones is a feasible strategy to increase crop productivity in these regions. This fact was observed for the potatoes in this experiment, under the $100 \%$ ETc water regime condition
(Figure 2), regardless of the fertilization used.

The water restriction directly influenced the reduction of the potato crop cycle cv. Orchestra, as observed in the treatments with plants submitted to the WR of $50 \%$ ETc ( 75 days) (Figure 2 ). This is explained by the fact that the accumulative irrigation depth is reduced, favoring an acceleration in the crop cycle, which in turn directly influenced smaller and larger tubers.

Netto et al. (2000) found that the increase in irrigation depth induced an increase in the leaf area index, in the leaf area duration, in the relative growth rate and in the net assimilation rate for potato cv. Aracy, directly corroborating the present study. Rodrigues et al. (2009) found that a long vegetative cycle provides greater productivity in temperate regions and is also an alternative for increasing tuber production under tropical conditions. For the potato crop, both the deficit and the excess of water are critical factors for its development and productivity (ABBA, 2003).

\section{Water use efficiency (WUE)}

For the WR 50\% ETc water regime, the analysis of variance of the WUE values did not reveal any difference for the type of fertilization, but there was a difference due to the mass of seed tubers (Table 4), with no interaction between the factors analyzed. The comparison of means showed higher WUE in the treatment with seed tuber mass $>50 \mathrm{~g}$ $\left(\mathrm{TS} 1=39.82 \mathrm{~kg} \mathrm{~m}^{-3}\right.$ of water), $36.2 \%$ higher in relation to seed tubers $<50 \mathrm{~g}$ (TS2 $=29.23 \mathrm{~kg} \mathrm{~m}^{-3}$ of water) (Table 4).

For the WR of $100 \%$ ETc, there was a difference for fertilization and seed tuber mass, and there was no significant interaction between the factors (Table 5). The largest WUE was obtained in the treatment based on the fertigation according to the rate of absorption by the $\operatorname{crop}\left(\mathrm{F} 2=25.32 \mathrm{~kg} \mathrm{~m}^{-3}\right.$ of water). WUE was similar in the treatments F1 and F3, with values of $21.80 \mathrm{~kg} \mathrm{~m}^{-3}$ of water and $22.42 \mathrm{~kg} \mathrm{~m}^{-3}$ of water, respectively. For the seed tuber mass factor, greater water use efficiency occurred in TS2 $(25.55 \mathrm{~kg}$ $\mathrm{m}^{-3}$ of water), $22.7 \%$ higher than TS1 (20.81 $\mathrm{kg} \mathrm{m}^{-3}$ of water) (Table 5). 
As the water supply decreased (50\% ETc regime), water use efficiency increased (Table 4). This result can be explained by the precipitations that occurred during the experimental period of the potato cycle (Figure 1B). Similar results were found by Muchalak et al. (2015), who carried out a study with water slides in drip irrigation with potato cultivars Asterix, Atlantic and CLL, and also found an increase in the USA. Fernández (2008) worked with potato irrigation levels in Santa Maria-RS and obtained the highest average of USA in the lowest applied irrigation depth (rain treatment $2003 / 04+25 \mathrm{~mm}$, average of $11.7 \mathrm{~kg} \mathrm{~m}^{-3}$ and peak of $\left.14.8 \mathrm{~kg} \mathrm{~m}^{-3}\right)$; and lower USA in the irrigated treatment (rains 2003/04 $+216 \mathrm{~mm}$, average of $\left.8.8 \mathrm{~kg} \mathrm{~m}^{-3}\right)$.

These results of water use efficiency are indicative of the possibility of potato cultivation in regions and periods of water scarcity and difficulties in food production (Mantovani et al., 2014). On the other hand, Arruda (2004) reports that difficulties could be faced when the tubers are destined for industry; for this purpose, larger diameter tubers and superior quality raw materials are preferred, which facilitate product processing and meet company requirements and consumer preferences.

Water restriction (WR of $50 \% \mathrm{ETc}$ ) reduced the cycle ( 75 days) and affected tuber productivity, the classification of tubers in large and small potatoes and the percentage of marketable tubers in potato $\mathrm{cv}$. Orchestra regardless of fertilization and seed tuber mass adopted in the present study.

The WR of $100 \%$ ETc prolonged the cycle (89 days) and positively affected tuber productivity, the classification of tubers in large potatoes and the percentage of marketable tubers in potato cv. Orchestra regardless of fertilization and seed tuber mass adopted in the present study.

The form of fertilization and seed tuber mass that positively influenced the studied variables were fertigation according to the culture absorption rate and seed tuber masses greater than 50 grams, for both water conditions $(100 \%$ ETc and $50 \%$ ETc).

Although the WR of $50 \%$ ETc has guaranteed greater efficiency in the use of water, difficulties can be faced with potato tubers cv. Orchestra when thinking about the commercialization process of this vegetable, as the industry and the consumer prefer larger and better quality tubers.

\section{ACKNOWLEDGMENTS}

The authors thank the Coordination for the Improvement of Higher Education Personnel (CAPES) for granting the scholarship that helped conducting the present study. We thank the company Agro Delgado for providing seeds of the potato cultivar Orchestra. We also thank the company NaanDanJain for providing the irrigation system and the company Yara for providing the fertilizers used in the fertigation.

\section{REFERENCES}

ABBA - Associação Brasileira da Batata. 2003. Irrigação da batata. Batata show, ano $3, \mathrm{n}^{\circ} 8$.

ALLEN, RG; PEREIRA, LS; RAES, D; SMITH, M. 1998. Crop evapotranspiration: guidelines for computing crop water requirements. Estudos FAO Irrigação e Drenagem 56. Rome: FAO. 328p.

ANDRÉ, CM; OUFIR, M; HOFFMANN, L; HAUNSMAN, JF; ROGEZ, H; LARONDELLE, Y; EVERS, D. 2009. Influence of environment and genotype on polyphenol compounds and in vitro antioxidant capacity of native Andean potatoes (Solanum tuberosum L.). Journal of Food Composition and Analysis 22: 517-524. Available https:// doi.org/10.1016/j.jfca.2008.11.010.

ARRUDA, CR. 2004. Análise das etapas do processamento de batata chips. Goiânia: UCG. $38 \mathrm{p}$ (M.Sc. dissertation).

BARBOSA, JC; MALDONADO JÚNIOR, W. 2015. Experimentação agronômica e agroestat - Sistemas para análises estatísticas de ensaios agronômicos. Jaboticabal: Multipress Ltda.

BAVUSO NETO, P; QUEIZOZ, RL; SILVA, EC. 2010. Viabilidade técnica da fertirrigação no cultivo de batata. Horticultura Brasileira 28: 1891-1897.

BERNARDO, S; SOARES, AA; MANTOVANI, EC. 2007. Manual de irrigação, 8.ed. Viçosa: UFV. 625p.

CEPAGRI, 2016. Clima dos municípios paulista. Available at: http://www.cpa.unicamp.br/ outrasinformacoes/clima_muni_279.html. Accessed January 18, 2019.

DENÍCULI, W; BERNARDO, S; THIÁBAUT, JTL; SEDIYAMA, GC. 1980. Uniformidade de distribuição de água, em condições de campo num sistema de irrigação por gotejamento. Revista Ceres 27: 155-162.
EMBRAPA - Empresa Brasileira de Pesquisa Agropecuária. 2004. Fertirrigação de hortaliças. Brasília: Embrapa. 13p. (Circular técnica)

EMBRAPA - Empresa Brasileira de Pesquisa Agropecuária. Centro Nacional de Pesquisa de Solos, 2018. Sistema brasileiro de classificação de solos, 5.ed. Rio de Janeiro: Embrapa Solos. 590p.

ERDEM, T; ERDEM, Y; ORTA, H; OKURSOY, H. 2006. Water-yield relationships of potato under different irrigation methods and regimens. Scientia Agricola 63: 226-31. Available at http://dx.doi.org/10.1590/S010390162006000300003.

FAOSTAT. 2018. FAOSTAT, banco de dados estatísticos, agricultura. Organização para alimentação e Agricultura. Roma.

FERNANDES, AM; SORATTO, RP; SILVA, BL. 2011. Extração e exportação de nutrientes em cultivares de batata: I - Macronutrientes. Revista Brasileira de Ciência do Solo 35: 2039-2056.

FERNÁNDEZ, SC. 2008. Morfofisiologia da cultura da batata submetida a diferentes regimes hídricos. Santa Maria: UFSM. 112p (M.Sc. dissertation).

FILGUEIRA, FAR. 2013. Novo manual de olericultura: agrotecnologia moderna na produção de hortaliças, 3.ed. Viçosa: UFV. $168 \mathrm{p}$.

GEISENHOFF, LO; PEREIRA, GM; JUNIOR, JAL; SOUZA, RORM; OLIVEIRA, ACF. 2016. Viabilidade produtiva da cultura da batata submetida a diferentes tensões de água no solo. Irriga 1: 306-318. Available at https:// doi.org/10.15809/irriga.2016v1n1p306-318.

HELDWEIN, AB; STRECK, NA; BISOGNIN, DA. 2009. Batata. In: MONTEIRO, JEBA (ed). Agrometeorologia dos cultivos: o fator meteorológico na produção agrícola. Brasília: INMET. p.281-293.

IBGE - Instituto Brasileiro de Geografia e Estatística, 2018. Levantamento sistemático da produção agrícola (LSPA) - Pesquisa mensal de previsão e acompanhamento das safras agrícolas no ano civil (Dezembro de 2018). Available at: https://sidra.ibge.gov. br/tabela/1618\#resultado. Accessed January 29, 2019

IBQH - Instituto Brasileiro de Qualidade em Horticultura. 2003. Programa brasileiro para modernização da horticultura. Normas de classificação do tomate. Centro de qualidade em horticultura. CQH/CEAGESP. Documento $\mathrm{n}^{\circ} 26$. Available at: http://www. hortibrasil. org.br/jnw/images/stories/folders/ tomate.pdf. Accessed January 27, 2019.

IWAMA, K. 2008. Physiology of the potato: new insights into root system and repercussions for crop management. Potato Research 51: 333-353. Available https://doi.org/10.1007/ s11540-008-9120-3.

KELLER, J; BLIESNER, RD. 1990. Sprinkle and trickle irrigation. New York: Van Nostrand Reinhold. 652p.

MANTOVANI, EC; SOUZA, DO; ZAMBOLIM, L; SEDIYAMA, GC; PALARETTI, LF. 2014. Produtividade da batata irrigada por gotejamento no sul do estado de Minas 
Gerais. Horticultura Brasileira 32: 63-68. Available http://dx.doi.org/10.1590/S010205362014000100010.

MAROUELLI, WA; GUIMARÃES, TG. 2006. Irrigação na cultura da batata. Publicação técnica. ABBA - Associação Brasileira da Batata. Itapetininga-SP. 66p.

MUCHALAK, SM; CUNHA, FF; GUAZINA, RA; LIMA, SF; GODOY, AR. 2015. Produção de diferentes cultivares de batata sob distintas lâminas de irrigação. Engenharia na agricultura 25: 66-476. Available http:// dx.doi.org/10.13083/1414-3984/reveng. v23n5p466-476.

NETTO, AOA; RODRIGUES, JD; PINHO, SZ. 2000. Análise de crescimento na cultura da batata submetida a diferentes lâminas de irrigação. Pesquisa Agropecuária Brasileira 35: 901-907. Available http://dx.doi. org/10.1590/S0100-204X2000000500006.

NICK, C; BORÉM, A. 2017. Batata: do plantio à colheita. Viçosa: UFV, 51p.

QUEIROZ, LRM; KAWAKAMI, J; MULLER, MML; UMBURURANAS, RC; ESCHEMBACK, V. 2013.Tamanho de tubérculo-semente e espaçamento na produtividade de batata em condições de campo. Comunicata Scientiae 4: 308-315.

RODRIGUES, GB; PINTO, CAB; BENITES, FRG; MELO, DS. 2009. Seleção para duração do ciclo vegetativo em batata e relação com a produtividade de tubérculos. Horticultura Brasileira 27: 280-285. Available http://dx.doi. org/10.1590/S0102-05362009000300003.

SILVA, LAS; PINTO, CABP. 2005. Duration of the growth cycle and the yield potential of potato genotypes. Crop Breeding and Applied Biotechnology 5: 20-28. Available: http:// dx.doi.org/10.12702/1984-7033.v05n01a03.

SILVA, JÁ; PIRES, RCM; SAKAY, E; SILVA, TJA; ANDRADE, JE; ARRUDA, FB; CALHEIROS, RO. 2007. Desenvolvimento e produtividade da cultura da batata irrigada por gotejamento em dois sistemas de cultivo. Engenharia Agrícola 27: 354-362. Available at http://dx.doi.org/10.1590/S010069162007000300004.

SORIANO, E; LONDE, LDR; GREGORIO, LTD; COUTINHO, MP; SANTOS, LBL. 2016. Crise hídrica em São Paulo sob o ponto de vista dos desastres. Ambiente \& Sociedade 19: 2142. Available: http://dx.doi.org/10.1590/1809- 4422asoc150120r1v1912016.

STRECK, NA; PAULA, FLM; BISOGNIN, DA; HELDWEIN, AB; DELLAI, J. 2007. Simulating the development of field grown potato (Solanum tuberosum L.). Agricultural and Forest Meteorology 142: 1-11. Available: https://doi.org/10.1016/j. agrformet.2006.09.012.

TEIXEIRA, AL; SILVA, CA; PEIXOUTO, LS; LEPRE, AL. 2010. Eficiência na emergência e produtividade dos diferentes tipos de batata-semente. Scientia Agraria 11: $215-$ 220. Available: http://dx.doi.org/10.5380/rsa. v11i3.17513.

VAN RAIJ, B; CANTARELLA, H; QUAGGIO, JÁ; FURLANI, AMC. 1997. Boletim 100: Recomendações de adubação e calagem para o Estado de São Paulo, 2.ed. Campinas: Instituto Agronômico/Fundação IAC, 173p.

ZHOU, Z; PLAUBORG, F; PARSONS, D; ANDERSEN, MN. 2018. Potato canopy growth, yield and soil water dynamics under different irrigation systems. Agricultural Water Management 202: 9-18. Available: https://doi. org/10.1016/j.agwat.2018.02.009. 